\title{
Redreaming ways of seeing: Ben Okri's intuitive creativity
}

\section{Rosemary Gray}

Rosemary Gray is emeritus professor in the Department of English at the University of Pretoria.

Email: prof.r.gray@gmail.com

DOI: 10.17159/2309-9070/tvl.v.55i2.2256

\section{Redreaming ways of seeing: Ben Okri's intuitive creativity}

Drawing on A Way of Being Free (1997) and A Time for New Dreams (2011) among other Okrian texts, this article is a discussion of the notion of redreaming ways of seeing through intuitive creativity. The argument is divided into three parts: the role of intuitive creativity; redreaming ways of seeing in The Landscapes Within (1981); and intuition or "the landscapes within". The deployment of John Berger's Ways of Seeing and Roland Barthes's Image, Music, Text posits an Afro-Western worldview in which the title of Okri's second novel effectively becomes a simulacrum for the lead character's psyche that supplants character per se, so that the "landscapes within" — the psyche — becomes the eponymous hero of the tale. The contention is that the complex inner workings of the mind of the artist-protagonist, Omovo, is both the signifier and the signified. This is supported by analyses of an Okri poem and extracts from the novel. I argue that, in contrast to its inter-art variants, René Magritte's 1935 Le faux miroir and La clef des songes, the novel invokes a neo-Platonic/Coleridgean concept of the "enlightening" eye as a correlative of Okri's notion of the inward visionary quest of the dreaming "soul" "opening towards infinity". The article concludes by briefly justifying the article's claim that, in this novel, art deals with inner reality, with "the landscapes within". Keywords: dreaming soul, intuitive creativity, Ben Okri, psyche, The Landscapes Within.

\section{Introduction: the role of intuitive creativity}

That Ben Okri's oeuvre reveals a preoccupation with an interweaving of dream, creativity, ways of seeing and intuition is borne out by a seminal statement in "Plato's dream", a chapter in his A Time for New Dreams: "All our creativity, our innovations, our discoveries come from being able first to see what is there, and not there; to hear what is said and not said. Above all to think clearly; to be nourished by silence. And beyond that-the art of intuition" (New Dreams 27). This resonates with Carl Jung's adage: "Who looks outside, dreams; who looks inside, awakens" (Jung, "Letter to Fanny Bowditch" n. p.).

The narrative of Okri's novel, In Arcadia (2002), is interspersed with "Intuitions". A pertinent instance of "intuitive creativity" can be found in A Way of Being Free: "Stories are one of the highest and most invisible forms of human creativity" (120). To awaken "the art of intuition" is thus to invoke poetic insight or mystical serendipities through heightened consciousness or ontopoiesis.

Prominent phenomenologists, such as the late Anna-Teresa Tymieniecka ("Aes- 
thetic expression of the moral sentiment" 11), hold that phenomenology or the ontopoiesis of life and contemporary scientific inquiry can meet "because the creative act of the human being offers royal access to the common enigmas of both". ${ }^{1}$ "All great stories are enigmas," Okri avers in his aphorism no. 97 in A Way of Being Free (126). In A Mystery Feast (15), Okri asserts that civilisations are distinguished by their "imaginative dimension". Reflecting on evidence of imaginative productivity in ancient Greece and Egypt, he declares that it is the imagination that "dreams that which knowledge makes real" and he concludes that "imagination is the proto-reality" (Being Free 126), as intimated in Jung's adage and my opening quotation from A Time for New Dreams. Similarly, the basic tenet of George Rowley's thesis in his discussion on the principles of Chinese art is the close kinship between artist and mystic. Reinforcing the affinity between artist and mystic, Rowley argues that while the mystic seeks "life more abundant", the artist "becomes a creator" (3). This resounds with Okri's belief in the primacy of the imaginary: the creative discovering act in storytelling, in turn, defines the numinous notion of "intuitive creativity".

The intention of this article is to explore a tentative idea of the creative horizon of Okri's notion of redreaming ways of seeing. "One of our much-neglected qualities is the creative ability to reshape our world. Our planet is under threat. We need a new one-planet thinking," says Okri in A Time for New Dreams (145). The phrases "redreaming ways of seeing" and "intuitive creativity" are therefore invoked to show that Okri's continual play of referentiality between and within his multi-generic texts foregrounds the composite or holistic nature of an Afro-Western cultural and historical context and heritage. As a Nigerian-born Londoner, Okri's entrapment through nature and nurture is in pre-existing patterns of thought, motif and form that tell of an inner conviction of mysticism and the eternal presence of the ancestors. And, as Rowley attests, these spiritual roots "lie deeply buried in the early orientation of the different cultures. They are the intangibles which embody the hopes and longings of a people; they are the incommensurables which determine the answers to the three basic issues of experience, Nature, Man, and God" (Rowley 3).

The symbiosis of the role of the dreaming imagination and intuitive creativity in art can be illustrated in the opening stanza to Okri's poem, "The difficulty of seeing" in Wild that points to the enigma of experience:

It feels odd to look long

At a corpse or a leaf:

It disturbs one's belief. (Wild 62)

This tercet alludes to the mystical conjunction between life (leaf) and death (corpse), and the way in which seeing impacts upon believing. Then, moving from a general observation to the inner affect, the poet is specific:

I found it hard to see 
My mother's face;

The more I looked,

The more her face eluded me.

I see her perfectly

In dreams, or when I don't try. (Wild 62)

The closing couplet to this insight into the elusive nature of visual recall or eidetic memory is movingly evocative. It reads:

Then long afterwards

I wonder why I suddenly cry. (Wild 62)

Here, a synaesthesia of the senses coalesces: a mirage becomes a fleeting illusion of reality, but only in dreams, while the elusion of perception evokes the heartfelt grief of bereavement as the poet attempts to re-imagine the beloved visage of his late mother. This poem at once echoes incidents in The Landscapes Within and reflects on the opening poem in Wild entitled, "My mother sleeps" (9-10). Both poems transpose into poetic form Okri's aphorism: "Love is the greatest creativity of them all, and the most blessed" (Landscapes 125).

Given that the basis for such creation or recreation is the imagination, but also involves the elixir of love plus such faculties as the senses, intuition and belief, the resultant artistic product must be both intuitively universal and culture-specific. The art work itself (be it performance, text, sculpture or painting) embodies and reveals the spirit of a people. As Rowley posits: "that spirit is so manifest that we seldom stop to ask why this pottery is Greek or that sculpture is Hindu, or why this figure must be Italian or that landscape English [...] Each culture seems to have had a special bent" (3). Yet, as intimated in the opening stanza of "The difficulty of seeing", that spirit also transcends cultural borders.

Acclaimed South African sculptor and poet, Pitika Ntuli, notes that, "the concept of African art, has been, and continues to be much contested" (10). It is important, therefore, to expand upon how Ben Okri can be defined in the context of intuitive creativity. His extensive travels, catholic reading tastes, incisive mind and artistic temperament have inevitably impacted on his ideological frame of reference. Anagnorisis or discovery of the true nature of one's own situation, keen observation and the absorption of influences from other times and other spaces are natural correlatives. Not unnaturally, therefore, his worldview or Weltanschauung is one of interconnectedness, interrelationships and interdependence, on the one hand, and of cosmic relationships, on the other. His role as creative artist is not unlike that of a sangoma, such as Ntuli, or a high-ranking healer: a mystical thinker.

The introduction criss-crosses reference to several Okrian texts to illustrate my contention that for Okri-as for other African writers-the way of seeing is not pri- 
marily through religion, philosophy or science but, as indicated in the amalgam of Okrian quotations above, is through art as the product of a grounded imagination. "When we see the unseen, hear the unspoken, that will be something amazing," says the intrusive authorial voice in Okri's latest novel, The Age of Magic (256). The plain prose meaning of this periphrasis is "redreaming ways of seeing".

In The Landscapes Within, Okri imagines ways in which to ameliorate multifaceted losses brought about by the bleak societal dysfunction in Nigeria. As he avers in $A$ Way of Being Free, "Whatever resilience has kept wounded people and devastated continents here, alive, can be transfigured to make them strong, confident, and serene. They have to question everything, in order to rebuild the future. They have to redream the world" (132, emphasis added).

\section{Redreaming ways of seeing in The Landscapes Within}

Set in war-torn Nigeria in the aftermath of the Biafran War, the story of Omovo in The Landscapes Within "begins" in medias res, with the recollection of a recurring nightmare, indicative of the subconscious mind grappling with the trauma of having witnessed the brutality of civil war. So, not only does the dream-inspired discourse predate both diegetic time and time of narration, but the narrative is also situated within a collective African unconscious. The novel is prefaced by two nightmarish dreams recorded in a real/fictive notebook; dreams which, in turn, become embedded in the text as a dreamtime echo of the novel's first climatic point at the end of Part One of this four-part novel. The narrative incident as formulation of the dream is a night-time encounter by two lost youngsters, Omovo and his journalist buddy, Keme, with the mutilated body of a young girl child in a park, bordering the beach. The incident and its dream replay dismantle essentialist notions of Nigeria; they leave an indelible "stain" of "guilt" (Landscapes 67) on the mind of twenty-year-old Omovo. This is exacerbated by his fictive memory of having helplessly [eye]-witnessed, at the age of nine, the wanton brutality of government forces against the Igbos during the Nigerian civil war of 1967-70.

These "incidents" not only create a hybrid portrait of the atrocities of civil warunderlined by later reference to past atrocities, the slave trade and colonialism, as well as to the present tragedy of neo-colonialism-but they also suggest that the sharing of horrific sights can connect human beings in empathy with one another, as Sope Maithufi (86) notes with regard to Okri's novel Dangerous Love (1988). Through these exophoric dynamics, the reader is projected into the historic or profane, concomitant with the mythic or sacred within the fictional as I observed in my reading of Margaret Atwood (Gray, "Divinatory simulacra in the novels of Margaret Atwood" 854). What is important for the general reader is that dream and intuitive creativity supersede anthropological or ethnographical factors.

According to Jane Wilkinson (2), Okri claims to imagine "two kinds of realities" in 
The Landscapes Within (in his aphorism no. 8). There is the tale of life in the slums of Lagos and the socio-political situation in post-civil war Nigeria; and then there is the tale of the inner workings of the mind of the young artist, Omovo, and the creative process in which he is intuitively involved. This section focuses on the trajectory of the latter which is towards "the moment" (Landscapes 272) when, in an epiphanic illumination or axis mundi (Gray, "When chaos is the god of an era: Rediscovering an axis mundi in Ben Okri's Starbook" 128-45) "the landscapes without synchronise with the landscapes within" (Landscapes 206). The synchronicity effectively illustrates intuitive creativity within a specifically African perception of proto-reality. Contrary to a reality that maintains "clear ontological boundaries between what [...] is usually designated as observed and imagined experience, material and magical phenomena, and real and fictional worlds", for Okri, as Derek Wright observes, "different and disparate worlds appear to coexist; there is an indeterminacy with regard to where literal reality ends and metaphor begins, a habitual elision of figurative and narrative space" (140).

This early novel can thus be read as an inquiry into ways of seeing informed by the process of intuitive creativity, as seen through the eyes of a prescient young black artist. Here, words seem to cast off their usual idiomatic sense; expressions fall painfully apart as the artist's vision shifts between what is seen and not seen. Consider the scene when, embarrassed but creatively aroused by the reaction of two men for having chastised some youngsters for taunting a goat and having experienced a lengthy "dry season" (Landscapes 4), Omovo rushes home to his drawing. In a prime example of intuitive creativity, "He worked and reworked the tentative lines, curves and shadings a hundred times [...] In the end he felt he had captured something more strange and real than the original sensation" (Landscapes 7). Of significance, here, is the conjoining of the sensual and the visual, as illustrated in Okri's poem about the difficulties of seeing, quoted in my introduction. This novelistic incident concludes with the forcefulness of the creative process, devoid of logic-a recreation of the seen that plunges the experience and the telling thereof into the surreal:

Omovo experienced a pure strain of joy.

He spoke quietly to the drawings: I have never seen you before. But it is wonderful that you are here.

"Omovo-o! Wetin be that you draw?" asked one of the compound boys.

"Why you draw the tree so?"

"Who tell you say na tree, eh?"

"If no be tree den wetin e be?"

"Mushroom. It be 'like big mushroom'."

"Na lie!" (Landscapes 7)

Here, the implied distillation of sense experience and perception, the "pure strain of joy" in the act of creation may have been fleeting-the reverie broken by mun- 
dane reality-but it evokes the mystical. The young artist is at once surprised and enchanted by his own drawing thus created and is moved to address the anthropomorphised artefact directly in hushed tones, one suspects so as not to disrupt the mystical experience. Becoming conscious of the "trifling argument" the work was causing, and looking at "the many sweaty, intent, indifferent faces", "a certain panic rose inside him". "Look," he said aloud. "Why don't you people just go away and leave me alone?" (Landscapes 7) Then, refusing to respond to a stranger's offer to buy the painting for resale to "Europeans", Omovo signs his charcoal etching and entitles it "Related losses" (Landscapes 8). The appellation encapsulates the pivotal theme of loss in this novel, prefiguring the later filching of the etching as well as the theft of his final painting of a faceless dead girl from his dream, likewise entitled, "Related Losses". This recalls the opening stanza to Okri's poem, "The difficulty of seeing" (Wild 62), quoted in the introduction, although the poem was written much later than his second novel.

In a different but pertinent context, John Berger considers what may be gained or lost by the intuitive creativity at play here: "The painter's way of seeing is reconstituted by the marks he makes on the canvass or paper" (3). Berger then shifts to reception aesthetics saying, "Although every image embodies a way of seeing, our perception or appreciation of an image depends on our own way of seeing [...] the more imaginative the work, the more profoundly it allows us to share the artist's experience of the visible" (Berger 3). Paradoxically, Omovo's fictional audience is either "indifferent" or lacking in artistic perception-unable to distinguish between tree and mushroom, causing a sense of "panic" in the young artist. Is the implication perhaps that civil war not only kills innocence, but also stultifies creative sensibility in ordinary citizens caught in the fray, so that loss of life and loss of spirit are two sides of the same coin in internecine strife? As noted in my earlier reading of the novel as an unfinished symphony, the pivotal trope (or figure of thought) in Okri's novel is the interweaving of an ever-shifting pattern of loss and revelation, experience and (artistic) formulation, dream and reality (Gray, "The Creative Imagination in Ben Okri's The Landscapes Within (1981)" 21-31).

Okri perceives of all art as storytelling, insisting in The Mystery Feast (15) that "[a] painting on a cave wall of a man pursuing a bison is a story. The frescoes of Giotto in Assise are distilled stories". It can be argued, therefore, that Omovo's titling of his paintings signifies the untold story(ies) of deprivation, trauma and longing embedded in the psyche of the emergent young artist who produces the art works, as well as in those of his fellow audience. Elaborating on the alchemy of artistic product-be it painting or story-in A Way of Being Free Okri muses: "It is easy to forget how mysterious and mighty stories are. They do their work in silence, invisibly. They work with all the internal materials of the mind and self. They become part of you while changing you" (120). 
This fragment just quoted concludes with a sombre caution to both reader and teller that doubles as a comment on the reactions of Omovo and his onlookers to his mysterious mushroom/tree painting: "Beware of the stories you read or tell: subtly, at night, beneath the waters of consciousness, they are altering your world" (Landscapes 7). Suggestive of the enigmatic nature of story, Okri elucidates in The Mystery Feast: "when we tell stories the ages awaken, when we listen to stories our future takes clearer shape" (15).

Citing the opening incident of the artist's decision to shave his head, and soon thereafter standing in the rain savouring "the flesh of his head tingl[ing]" (Landscapes 6), Alain Severac notes that the "scene constitutes the luminary aesthetic statement" postulating "a flayed sensitivity as a prerequisite of artistic creation" (76). In the context of Okri's claim in A Way of Being Free for the imagination as "one of the highest gifts we have" (126), coupled with the meaning of the Benin name Omovo-a (male) child from above-the shaven head is a complex symbol: a local signifier of loss (Omovo had just lost his mother); but it is also a way of "feeling the body from within" (78) to use Eckhart Tolle's term, of self-awareness stimulating the imaginative faculty. The "child from above", an abiku or spirit child exists liminally "somewhere in the interspace between the spirit world and the Living," says Okri (Ross 337). He explains that the $a b i k u$, the central figure in his famed "famished road" trilogy, lives "simultaneously at different levels of consciousness and in different territories" (see Wilkinson 53). It can therefore be argued that the sensation of rain beating on Omovo's bald head allows Okri's desire for "a new one-planet thinking" or the joy of Being to flow into everything. Rain on the shaven head facilitates insight, enabling the young artist to be more alert, to see more clearly. In effect, it opens what Albert Camus calls "a whole proliferation of phenomena" (27) to intuition, to the heart. An awakened consciousness, or what Tymieniecka ("Phenomenology of Space and Time" 12) calls ontopoiesis, leads to what Okri repeatedly refers to as "The Moment" (Landscapes $206,272,286$ ). This is metonymic for enlightenment or satori, a flash of insight. ${ }^{2}$ The shaven head thus evokes "the transcendence of the egoic mind and the possibility of living in an entirely new state of consciousness, of 'learning all over again to see, to be attentive, to focus consciousness' $[\ldots]$ turning every idea and every image [...] into a privileged moment" (Camus 26). By contrast, Berger would perceive images—such as the shaven head or the mushroom tree-more objectively, as "a direct testimony about the world which surrounded other people at other times" (2-3). He imagines an unspoken dialogue with the visible world, "an attempt to explain how, either metaphorically or literally you see things, and an attempt to discover how 'he sees things'" (Berger 3, emphasis added). Roland Barthes is more linguistically inclined, asserting that "there is no perception without immediate categorization" (28). In this context, both these images - the bald head and the mushroom-like tree-are devoid of denotation: they have their own "inner metalanguage". This is closer to both 
Rowley's and my earlier argument about African ways of seeing. Barthes explains that this language is that of perceptive connotation embedded in "its very social existence" (29), likewise alluded to in the discussion on African epistemology. Barthes explains: "[T]he text constitutes a parasitic message designed to connote the image, to 'quicken' it with one or more second-order signifieds" (25). However, contrary to my reading, the shaven head signifier would, in these terms, seemingly remain a culturally deferred sign, rather than a more complex conflation of signifier and signified. Pondering the purpose of the signifier, Barthes muses, "its purpose is less the analysis of the sign than its dislocation" (166). As already intimated, in a Nigerian cultural context, shaving one's head is a customary sign of bereavement. In this poetic novel and in the context of redreaming ways of seeing, the experiential rests on the perceptual and sensory, giving rise to the cerebral and ultimately the spiritual. In this context, rain on the shaven head is symbolic: it signifies an awakening of a sleeping world, of making what is seen vivid to the mind, and perhaps even of seeing with the third eye (as suggested by the cover illustration to The Landscapes Within as well as a painting of an all-seeing eye by Omovo's mentor (discussed later), themselves a transliteration of René Magritte's Le faux miroir (False mirror)).

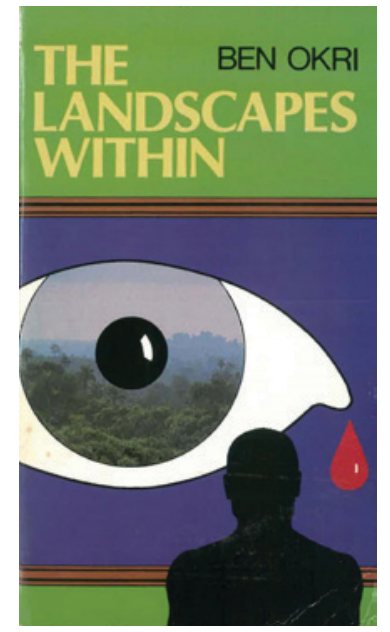

Figure 1: Front cover of The Landscapes Within

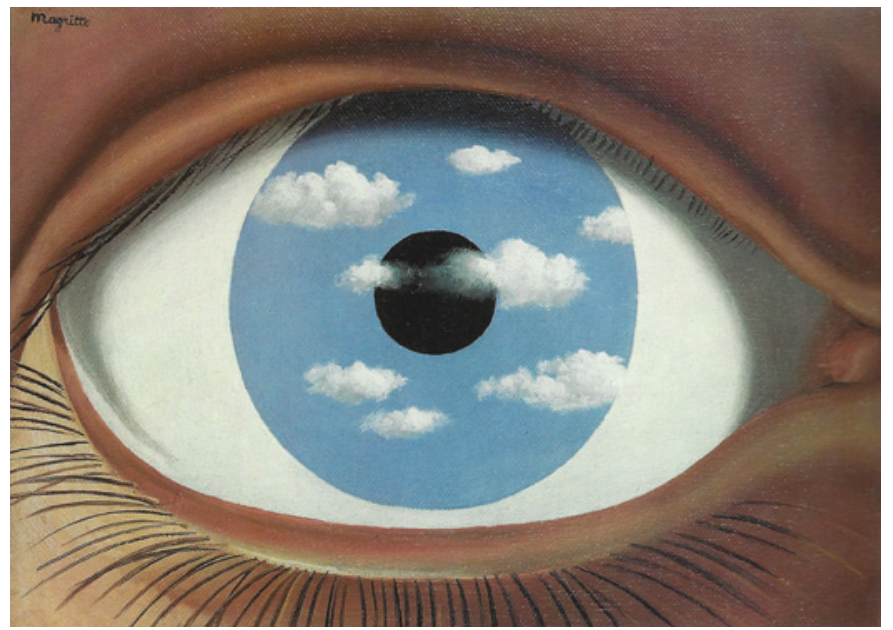

Figure 2: René Magritte, Le faux miroir

The similarity between Magritte's famed eye and Okri's cover illustration provides the lens through which the article views Okri's novel-as invoked by both Omovo's irritated response to the village youngster's well-meaning but naïve questions and the young artist's heightened consciousness.

Notions of coexistent proto-realities are explored and extended throughout this novel via the interplay between sharply etched reflection or daydreaming, on the one hand, and an imaginative recreation in Omovo's mind and, thence, onto his 
canvass, on the other. Privileging the complexities and contradictions inherent in the process of self-awareness-made manifest in the bald head trope-sharpens the perception that this narrative, as an art form, is incapable of miming or mirrorreflecting a single perspective; it is non-mimetic and suggests that dreams create the kind of speculation that is most fruitful for artistic creation as in Magritte's La clef des songes (The key to dreams). And, as with the Magritte cameos of the interpretation of dreams, Okri tends to resist the idea that meaning is a given or can, indeed, be given in The Landscapes Within. This typifies the mode of the $19^{\text {th }}$ century French symbolists, whose art of expressing ideas (and emotions) eschews direct description and even similes and metaphors. Okri follows their strategy: one of recreating the ideas/sense impressions in the mind of the reader using unexplained symbols (see Chadwick).

This then is the story of the operation of intuitive creativity in a developing artist in a Lagos ghetto. Intense visions suggest a desire to encapsulate the creative process within a chaotic slum milieu. Omovo consoles, suffers, dreams, etches, paints and has visions. Consider, for example, his eerie encounter with a huge painting of Christ on the cross which, coupled with witnessing a figure dying tortuously of stab wounds outside the church, culminates in momentary night blindness with his soul being "plunged in a soft hued area of nothingness" (Landscapes 221), precipitating a new knowledge of self. To see what is going on in the art of great writers or painters, one must first be established in "the art of oneself" says Okri in A Time for New Dreams (23). Seen through Omovo's eyes, the painting is described as an emanation of the danse macabre:

The cross was done in thick black and was rather like a stake with jutting spiked ends, a thing of incarnate evil. Christ was depicted as a diminutive madman and the suffering rendered on his face, from which foam issued strangely, seemed so intense that it did not look like suffering or anguish. It looked like maniacal laughter. The blood that blurted from his impaled hands and feet was the colour of red wine streaked with violets and whites. It was a crude painting. (Landscapes 220)

Omovo's blinded perception of Christ's crucifixion is of the grotesque: blackness, evil, insanity, distortion and exaggeration, symbolic of the darkness of life. In a shocked volte face, the depiction transmutes into a metonym for the suffering of his own people as the artist is drawn to identify with the "diminutive madman" portrayed in his own likeness-as a tiny black-skinned figure rather than the customary white bearded shepherd of western iconography:

The painting might not have been about Christ at all. Then he looked at the face again. A shock exploded inside him when he realised that the face had been done in black and his thoughts seized and his mind ran riot and he had no control over the pains and the pains threatened to drown his mind and he wanted to scream madly and he opened his mouth and the sounds and furies fought themselves [...] (Landscapes 220) 
The identification is enhanced by the choice of "seized", the onomatopoeia serving to endorse the resultant speechlessness; the "intense pain" that caused both mind and voice to "seize".

Barthes's claim in Image, music, text that "the image no longer illustrates the words; it is now the words which, structurally, are parasitic on the image" (28, original emphasis) seems to pertain to this excerpt. It is as if the mystery of art—and books dealing with artistic endeavour, such as The Landscapes Within — can only be confronted rather than interpreted. Art, like life, is here seen as a revelation of the horror of inhumanity posed against the mystery latent in all things. In sum, therefore, as Barthes states: "it is not the image which comes to elucidate or 'realize' the text, but the latter which comes to sublimate, patheticise or rationalise the image" (28).

Okri's view is therefore closer to that of Barthes than to Berger's as is also captured in his statement in A Time for New Dreams that, "To see the true art or the truth in a work requires solid foundation in self" (24). In his text, African Art, Ivan Bargna elucidates this Okrian aphorism, stating that, "African art can be considered a relational field in which the identity of everything that exists depends on the strength that is in everyone, which in turn depends on the position it occupies in the web which makes up the world and whose map is furnished by tradition" (Bargna 15).

So, whereas Berger points to the centrality of reception aesthetics, to the reciprocity between the art work and viewer response, Okri's canvas is more deeply personal and cultural. Like Bargna's it is also mystical, presupposing an engagement with the unknowable by the reader. "Otherwise," Okri explains in A Time for New Dreams, "like light passing through a transparent object the work of art passes straight through an unformed mind and heart" (24).

As I argued in my earlier reading of this seminal novel (Gray, "Creative imagination" 21-31), the initial, graphically rendered dream is of an endless trek through a "terribly dark forest" where trees became coloured mist then mutate into a vision of the faceless corpse. In the second interrelated nightmare, the artist's mind is confronted by a huge, "terribly blank canvass" (Landscapes 3 and 64, emphasis added). A kaleidoscopic milieu of "coloured mountains", "turbulent and calm seas" and "primeval forests", reminiscent of Magritte's "The key to dreams" mentioned earlier, form the backdrop for the appearance of the dead girl "seen" walking towards, but never quite reaching Omovo, before he again wakes in shock with a sense of unutterable loss and "a mad urge to capture" (Landscapes 64) the elusive vision on canvas, a feat that he manages only towards the end of the novel—tellingly a painting, like the dream and Okri's own haunting attempt to recapture his own dead mother's face, "without a face", and also entitled "Related losses" (Landscapes 281), as already noted. The loss echoes that of Omovo's stolen painting of emaciated children playing around a mushroom-like truncated tree (Landscapes 5), already discussed. 
These dreams dictate the narrative thrust and tone of Okri's second novel becoming, in turn, simulacra for the mercurial nature of the creative process (of both painting and writing) reminiscent of Ted Hughes's poem, "The thought fox". ${ }^{3}$ Okri's imaginative rendering of the workings of the subconscious mind penetrates deeply into the narrative thread and structure of The Landscapes Within, defining its section themes of "Loss", "Mazes", "Masks" and "Fragments", and culminating in the focal character's brief insight into the meaning of "The Moment" (286). ${ }^{4}$ Ultimately, the novel offers an imaginary resolution to socio-political and personal conflicts: "It's about surviving," Omovo comes to understand, "but it's more about becoming a life artist" (286).

Okri repeatedly attributes the oneiric (dreamtime) records in The Landscapes Within to "painter boy" (4, 35 and 197), Omovo. The dreams of the mutilated body "haunt the novel and [are] returned to again and again" as noted by Adewole Maya-Pearce (92). This recurrence is integral to the author's way of seeing, coupled as it is with Omovo's obsessive recording and rereading of the dreams in a notebook, itself implying that self-reflection is an intuitive creative imperative. This is highlighted by an internal reflection on a drawing Omovo had done at the tender age of seven of "a series of squiggly lines that went round and round and formed different shapes", which his teacher and his father had eulogised as capturing "life" (Landscapes 95, 96), but which he was never again able to emulate. The intrusive authorial voice explains why: "The boy somehow understood that he had done it once but could not do it again till he really knew how" (Landscapes 96). The reminiscence is typically Okrian, typically oblique. Is the implication, to borrow loosely from Tymieniecka that, in the impoverished theatre of slum life, "all the forces and dynamisms of human existence stew" ("Aesthetic expression" 26)? And, owing to the freely inventive nature of a very young boy's creativity and his struggle to capture something of the essence of existence, the artistic enactment loses its foothold, becoming detached from any foothold. An additional implication is that art is not and cannot be complete; the artist continuously mediates life's predicaments, especially when these recur throughout history. I. A. Richards's insight, in his edition of Plato's Republic, into lines, circles, triangles, such as those in the child's painting, endorses this interpretation: "The lines of geometry belong to the world of Being; those the geometer may draw to the world of Becoming. He uses them to help him to think about Forms-in the world of Being. Forms themselves are not able to be seen or drawn, but they can be thought of" (7).

So, far from developing into a Bildungsroman, the novel remains-and this, paradoxically, is its brilliance- an unfinished Kunstlerroman, climaxing in the young geometer/artist's recognition of the elusive evanescence of insight/knowingness: “I'm still learning,", Omovo insightfully explains to Keme before reading him his elder brother, Okur's poem, which captures the same ephemeral nature of seeing: "Searching for bright pebbles / and strange corals" on the seashore as a small child, Omovo's brother 
writes that the poetic persona sometimes saw them "hidden and clear", but found "other things too / like half-defaced sketches on the sand / pointing a way through the tormented seas" (Landscapes 286). Here, the "half-defaced sketches" encapsulate not only the mystery of how an empty sea shell can bring forth a musical echo of the sea-a melding of the concrete and the abstract, but also the illusory fleetingness of artistic insight: "The world of Becoming is indescribable—except through Forms (Ideas) of the world of Being" (Richards 7).

Earlier in the novel, Omovo shares a comparable moment of illumination/intuition with the young Ayo, son of the chief in the village near to the city of Lagos where Omovo has sought respite after the triple losses of an evanescent vision of his beloved dead mother (revisited in "The difficulty of seeing"); losing his job; then the loss of his lover, Ifeyinwa, who has been shot, a casualty of internecine strife, in the forest near her home while escaping from her abusive elderly husband. "I had an unconscious glimpse into profound and magical, solid and undefinable beauty; its strange and soundless music; its vanishing and unearthly lights", he tells Ayo. Attempting to recapture the "quintessential" and "beatific" vision, Omovo laments that he felt "desperate and empty [...] seeking for so much as another glimpse through the tiniest crack of that door" (Landscapes 270). The triple losses shift the vision into a metaphysical dimension evocative of Coleridges's Aids to Reflection that reads: "Nothing is wanted but the eye, which is the light of this house, the light which is the eye of the soul" (70) (Here, the word "wanted" is, of course, used in its archaic sense of "lacking".) The eye, Coleridge continues is

This seeing light, this enlightening eye, is Reflection. It is more [...] it is what a Christian ought to mean by it and to know, too, whence it came [...] of what light even this light is but a reflection. This too, is THOUGHT, and all thought is but unthinking that does not flow out of this, or tend towards it. (Coleridge 70)

\section{Inner reality or "the landscapes within"}

The catalytic dreams/nightmares, and their incorporation into the narrative, are thus methodological, defining not only ways of seeing in this novel, but also intuitive creativity. In The Landscapes Within, Omovo's paintings parallel his dreams as "a means to explore the deeper, more unconscious meanings and miasma of his life and the landscapes about him". His painting and, by extension, his dreams are "a part of his response to life: a personal prism" (Landscapes 85). ${ }^{5}$

The landscapes within thus become axiomatic to both the narrative point of view and the novel's symbolism, effectively supplanting Omovo as lead character, and making Omovo's creative imagination, his heightened consciousness, the eponymous hero of this early novel. The signifier and the signified conflate, becoming an awareness, a mode of perception: a presence rather than an agent. The spirit child's brief "moments" of insight evoke the Zen moment of no-mind and total presence, 
incomprehensible to the intellect. Both Okri's title and the narrative itself tacitly refer to the "landscapes of the mind" (Landscapes 18).

After completing his second painting (of a scum pool) and before it is confiscated by the authorities as unpatriotic (as "caricaturing the nation's progress"), Omovo intuits "that the future was contained somewhere in his mind" (Landscapes 139). Mystified by the furore that the picture engenders, Omovo states: "I simply painted a scumscape as I saw it" (Landscapes 139, emphasis added). The recurrent scum motif is thus externalised in the painting that he calls Drift. As Magritte famously, or infamously, retorted when pressed for the meaning of an art work: "visible things always hide other visible things. But a visible image hides nothing" (Sylvester 318, original emphasis). This aligns itself with Barthes's insistence that every image is a complex text.

Omovo's mentor, Dr Okocha, had painted a single eye on his work shed door: "a brooding green eye, with a black pupil and a gathering red teardrop: which "stared all-seeingly at the teeming streets and back into its own darkness" (35). As stated, this painting features on the cover of The Landscapes Within, and it seems to be an analogue for a public prism, reminiscent of Magritte's Le faux miroir. The eye is a simulacrum for the mind's eye.

In Plato's Republic, Socrates provides a useful explanation of the conflation of the extrinsic and the intrinsic:

[T]he natural power to learn lives in the soul and is like an eye which might not be turned from the dark without a turning around of the whole body. The instrument of knowledge has to be turned round, and with it the whole soul, from the things of becoming to the things of being, till the soul is able, by degrees, to support the light of true being and can look at the brightest." (Socrates qtd. in Richards 5, emphasis added)

In implied comment on its assumed inter-art variant, Magritte's 1935 Le faux miroir, suggestive of imperfect perception or mystical perception, this eye invokes the neo-Platonic/Coleridgean concept of the "enlightening eye", just mentioned and is reminiscent of Okri's notion of the creative process as the inward visionary quest of the dreaming "soul" opening "towards infinity" (Wilkinson 2), cited earlier.

This ontopoietic text concerns itself with "the imaginative realm, as opposed to the landscapes without, i.e. the physical world" as attested by Daria Tunca (96). Even the story within the story, an illicit love affair borne of innocence, is imbued with heightened consciousness. The brief union with Mr Takpo's young wife, Ifeyinwa, with whom Omovo shares a love of reading and art, is one of complementary spirits and yearnings (caritas) as opposed to carnality. "He became for her something of a spiritual husband, one that she only confronted fully in her dreams and fantasies" (103). Likewise a dreamer, Ife voices her grievance about her arranged marriage to an old and brutal man by saying to Omovo, "You have your art. I don't have any- 
thing" (Landscapes 25), thus forging a link between the two narrative threads and the third person authorial voice, as I pointed out in my initial reading of this text. Nonetheless, it is as if, in her suffering, Ife stumbles upon the redemptive nature of artistic creation, enabling a more transcendent way of being even in the midst of abuse, poverty and deprivation.

More euphemistically but equally ephemerally, Okri writes of another pair of his lovers, Lao and Mistletoe in The Age of Magic: "If they knew how, they could have walked through the mirror of beauty into a shining world. In that moment, between strides, they could have seen that nothing was meant to be, but only what they made it. They could have rewritten their lives on the margins of the book of life" (Magic 228).

"The novelist," asserts Kundera pertinently in The Art of the Novel "makes no issue of his ideas" (144).

He is an explorer feeling his way in an effort to reveal some unknown aspect of existence. He is fascinated not by his voice but by the form he is seeking, and only those forms that meet the demands of his dream become part of his work [...] The writer inscribes himself on the spiritual map of his time, of his country, on the map of the history of ideas. (Kundera 144).

As already intimated, the title of Okri's novel is a poetic compression of an AfroWestern Weltanschauung. As Simon Schama asserts, "landscapes [for the African] are culture before they are nature"; they are "constructs of the imagination projected onto wood and water and rock" (61) and, by extension, paper.

For a writer such as Okri, existence in the modern world can best be understood through his literary representations of imaginary landscapes. The episode in which Omovo caricatures one of his work colleagues as the realisation of his own imminent dismissal, following the machination of this colleague, dawns upon him underlines my point. "Drawing made him reminisce; it could be so lonely. In his mind rose the fleeting, blurred images of some of the things he had drawn and painted passionately in the past [...]" (Landscapes 199); a reminiscence that leads to a stream of consciousness recollection of the classic film, "The lost horizon", and its elusive catchy theme tune-a synthesis of the visual and the auditory.

Okri's early oeuvre is redolent of African influences yet, paradoxically perhaps, speaks to western sensibilities in a variety of intriguing conversations. As argued in my earlier article on the The Landscapes Within as an unfinished symphony, the novel epitomises the polyphonic mode, blending as it does dream/narrative/poetry and instinct/intuition/vision. ${ }^{6}$ An analysis of any excerpt reveals comparable counterpointing. Consider, for example, the artistic braiding when Omovo tries to explain what he has learnt about the idea of the Moment to his journalist friend. As intimated, first, there is repartee as Keme presses Omovo to divulge what he had said about the Moment; then, Omovo has a vision and a revelation which coalesce in "I thought 
I sensed a brilliant shadow of a god. I think I saw, instead, one of those rare faces horribly mirrored in us [...] But I'm learning something also though" (Landscapes 286) leading to the bit about surviving and becoming a life artist, already quoted. All facets are bound by a common fugue-like theme: ways of seeing.

In The Age of Magic, Okri seems to corroborate this interpretation by having his lead character, Lao, discuss these abstractions and the attendant loss with his artist companion. The conversation goes as follows as Mistletoe continues to muse:

"[...] There's much more to life than what we see."

Lao retorts: "Believing only what we see enshrines only what can be seen."

"And so we don't question what we don't see."

"But often we are brought down by the unseen."

"I know: Anxiety, neurosis, stress, cancer."

"By the time we see what they are doing to us it's too late."

"We treat the symptoms, and die."

"But the causes are unseen."

"And because they are unseen we don't believe they exist."

"There's something primitive about the phrase 'Seeing is believing', don't you think?" said Mistletoe.

$[\ldots]$

"Truth seems upside down"

"And inside out." (256-7)

The prevailing question in The Landscapes Within is couched in a novelistic essay on loss. The essay on loss incorporates a litany of losses: including loss of homeland; getting lost; loss of lives; wives; mothers and lovers; fathers and brothers; paintings; identity (the mutilated girl and Ife become faceless non-entities), fortunes; and loss of face; culminating in the piece of coral without its heart, which Omovo throws back into the sea at the close of the novel. The usage is, however, as much playfully connotative as it is denotative. The word "loss" is woven into a complex tapestry of symbols and signs. ${ }^{7}$ This extracts its significance from its rational context and places it in a context accessible only through the interpretative imagination. Submerged by the indefinable, the metaphor of loss conceals more than it transmits, thus counterpointing the exploration of the other key abstract concepts: intuitive creativity, corruption, dream, integrity, perception and responsibility. ${ }^{8}$

Ultimately, this novel deals with ways of seeing, with subjects that can be thought about but cannot be known; with the fluidity of "the landscapes within". What this suggests is intuitive creativity, where "Creativity is," as Okri states in A Way of Being Free "a secular infinity" (125). The artist/novelist here, perhaps inadvertently, reveals 
both the inside of life, and the outside. He is a Jungian dreamer who awakens. To quote Rowley (3), "This creation is the product of the imaginative 'wedding of spirit and matter $[\ldots]]^{\prime \prime \prime}$ (see Smith 4).

\section{Conclusion}

The argument of this article has been that the novel is predicated on the autonomy of art and the autonomy of the real. Kundera elucidates on the significance of the oneiric narrative, saying: "Imagination, freed from the control of reason and from concern for verisimilitude, ventures into landscapes inaccessible to rational thought" (78). The Landscapes Within is a compelling meditation on existence-ways of seeing and intuitive creativity-through the medium of imaginary internal and external landscapes, seamlessly connecting consciousness and unconsciousness. As Wright observes in a coincidental summing up of my argument about Okri's writing: "There is [...] an inward movement away from protest and polemic and towards interior psychic healing; there is also a visionary introjection of the world into the artistic consciousness that places a tremendous emphasis on the redemptive energies of dream, myth and the imagination [...] (159). In the context of semiotics and mythology, Barthes pertinently states: "[...] the new semiology—or the new mythology - can no longer, will no longer be able to, separate so easily the signifier from the signified, the ideological from the phraseological" (166). "It is not," he explains, "that the distinction is false or without its use but rather that it too has become in some sort mythical" (Barthes 166). This seems to suggest that ways of seeing have undergone an intuitive transformation. Wright points to the operation of intuitive creativity in a comparable mystical context: "For Okri, redemptive energy is finally not a political but a purely visionary, imaginative quality" (60). In A Time for New Dreams, Okri writes of another young artist, this time a Spaniard, and his first encounter with African masks, a life changing looking "inside" moment of the kind that Jung believes "awakens" and that serves to illustrate Okri's articulation of the visionary redemptive energy of the imaginary: "He had been touched into life by the ancient myth of the superman and by the brilliant angel of the beautiful darkness. A darkness that was, in truth, a new light" (66).

\section{Acknowledgements}

This article was made possible by incentive funding from the National Research Foundation, South Africa. The author acknowledges her own earlier reading, entitled "The creative imagination in Ben Okri's The Landscapes Within (1981)", presented at Harvard in June 2012 and published in the English Academy Review: Southern African Journal of English Studies (vol. 30, no. 2, 2013, pp. 21-31). The thrust of that article was narratological, reading the novel as an unfinished symphony. 


\section{Notes}

1. Tymieniecka explains "It is only by isolating from the self-ordering of beingness, cosmic and living, the nature of beingness as such-its ontopoietic-ontic status - that is, by rooting ontopoietic ordering within its originary condition, thus entering into linea entis, that we may bring out the central conduit of existential becoming, the conduit of the logos of life that proceeds from the unfathomable part and leads towards an open-ended future and which situates and explains the essential status of concrete existence in the space of the present. This conduit of becoming I appropriately call the ontopoiesis of life" ("Aesthetic expression" 13).

2. Tolle states: "Zen masters use the word satori to describe a flash of insight, a moment of no-mind and total presence [...] Presence is needed to become aware of the beauty, the majesty, the sacredness of nature" (79).

3. Ted Hughes's (3) poem reads: "I imagine this midnight moment's forest: / Something else is alive / Beside the clock's loneliness / And this blank page where my fingers move. // Through the window I see no star: / Something more near / Though deeper within darkness / Is entering the loneliness: // Cold, delicately as the dark snow/ A fox's nose touches twig, leaf; / Two eyes serve a movement, that now/ And again now, and now, and now // Sets neat prints into the snow / Between trees, and warily a lame / Shadow lags by stump and in hollow / Of a body that is bold to come // Across clearings, an eye, / A widening deepening greenness, / Brilliantly, concentratedly, / Coming about its own business // Till, with a sudden sharp hot stink of fox / It enters the dark hole of the head. / The window is starless still; the clock ticks, / The page is printed".

4. Elsewhere, Okri calls this "an Akashic Still Point" (see Gray, "Apologia pro Ben Okri's In arcadia: A neglected masterpiece?").

5. Omovo's painting and, by extension, his dreams we are told "was part of his personal prism" (Landscapes 85). Significantly, the phrase is altered in the "re-writing and expansion" (Jowitt 62-3) to "a personal and public prism" (Dangerous Love 69).

6. "Polyphony in music is the simultaneous presentation of two or more voices (melodic lines that are perfectly bound together but still keep their relative independence)" (Kundera 73-4).

7. In addition to multiple losses of life-the girl; Omovo's mother; Ife's brother drowns; she is shot, Keme's sister goes missing; Omovo's stepmother loses an unborn child; his dad kills Tuwo for cuckolding him-Okri includes loss of fathers: Ayo's and Omovo's imprisoned father loses himself, becoming "a shrivelled presence" (Landscapes 282); of jobs, fortunes, dignity, sanity, innocence, art works, and of country (Dele escapes to America, to freedom, but ironically, he runs, because he has impregnated his Nigerian girlfriend, and paradoxically, because he cannot wait to experience sex with a white woman).

8. A theme in the novel, which becomes more apparent in its rewriting as Dangerous Love is the artist's "responsibilities" (Landscapes 278).

\section{Works Cited}

Bargna, Ivan. African Art. Java, 2000.

Barthes, Roland. Image, Music, Text. Hill and Wang, 1977.

Berger, John. Ways of Seeing. Penguin Modern Classics, 2008.

Camus, Alfred. The Myth of Sisyphus and Other Essays. Trans. Justin O'Brien. Random House, 1983.

Chadwick, Charles. Symbolism. Methuen, 1973.

Coleridge, Samuel Taylor. Aids to Reflection. Aphorism IX, ed. Henry Nelson Coleridge. Chauncey Goodrich, 1840, pp. 161-210.

Gray, Rosemary. "Apologia pro Ben Okri's In Arcadia: A neglected masterpiece?" English Academy Review vol. 26, no. 1, 2009, pp. 41-52. DOI: https://doi.org/10.1080/10131750902768408.

"Divinatory simulacra in the novels of Margaret Atwood." Myths. rites, simulacra: Semiotic viewpoints. Eds. Jeff Barnard and Gloria Withalm. Die Deutschen Bibliothek, 2000, pp. 853-6.

. "Ontopoiesis in Ben Okri's poetic oeuvre and A Time for New Dreams." Analecta Husserliana vol. CXVI, 2014, pp. 49-58.

"The creative imagination in Ben Okri's The Landscapes Within (1981)." English Academy Review: Southern African Journal of English Studies vol. 30, no.2, 2013, pp. 21-31. DOI: https://doi.org/10.1080/ 10131752.2013.834683.

. "When chaos is the god of an era: Rediscovering an axis mundi in Ben Okri's Starbook (2007)." Research in African Literatures vol. 44, no. 1, 2013, pp. 128-45. http://www.jstor.org/stable/10.2979/reseafrilite.44.1.128. 
Hughes, Ted. New Selected Poems 1957-1994. Faber, 1995.

Jowitt, David. "Review of Dangerous love." Wasifiri vol. 24, 1996, pp. 62-3.

Jung, Carl Gustav. Letter to Fanny Bowditch. 22 October 1916. Carl Jung Depth Psychology. 8 Feb. 2018. carljungdepthpsychologysite.blog/2018/02/08/carl-jung-i-am-afraid-that-the-mere-fact-of-my-presencetakes-you-away-from-yourself/. Accessed 18 May 2018.

Kundera, Milan. The Art of the Novel. Faber and Faber, 1988.

Maithufi, Sope. "The Inward and Outward Trajectories of the Shaman's Journeys: Mediation in Ben Okri's Dangerous Love and Zakes Mda's The Sculptors of Mapungubwe." Journal of Literary Studies vol. 32, no. 2, 2015, pp. 81-93. DOI: https://doi.org/10.1080/02564718.2015.1058551.

Maya-Pearce, Adewole. A Mask Dancing. Hans Zell, 1992.

Ntuli, Pitika. Pitika Ntuli: Scent of Invisible Footprints. U of South Africa P, 2010.

Okri, Ben. A Time for New Dreams. Random House, 2011. . A Way of Being Free. Phoenix, 1997.

. Dangerous Love. A. D. Donker, 1996.

. In Arcadia. Phoenix, 2002.

. The Age of Magic. Head of Zeus, 2014.

. The Landscapes Within. Longman, 1981.

. The Mystery Feast. Clairview, 2015.

. Wild. Random House, 2012.

Richards, I. A. Plato's Republic. Cambridge U P, 1996.

Ross, Jean. "Contemporary authors interview (with Ben Okri)." Contemporary Author vol. 138, ed. Donna Olendorf. Gale Research, 1993, pp. 337-8.

Rowley, George. Principles of Chinese painting. Princeton U P, 1947.

Schama, Simon. Landscapes and Memory. Harper Collins, 1995.

Severac, Alaine. "Dangerous Love: Okri's metafiction." Theory and Literary Creation/ Théorie et création littéraire, ed. Jean-Pierre Durix. Editions Universitaires de Dijon, 1999, pp. 175-85.

Smith, Anna. "Dreams of cultural violence: Ben Okri and the politics of the imagination." World Literature Written in English vol. 38, no. 2, 2000, pp. 44-54.

Sylvester, David. Magritte. Thames and Hudson, 1992.

Tolle, Eckart. The Power of Now. Hodder \& Stoughton, 2005.

Tunca, Daria. "Ben Okri's The Landscapes Within and Dangerous Love: Vision and revision." BELL: Belgium Journal of English Language and Literatures vol. 2, 2004, pp. 85-101.

Tymieniecka, A-T. "Aesthetic expression of the moral sentiment." Phenomenological Inquiry vol. 28, 2004, pp. 5-35.

. "Phenomenology of Space and Time." Analecta Husserliana. vol. CXVI, 2014, pp. 3-36.

Wilkinson, Jane. Talking to African Writers. James Currey, 1992.

Wright, Derek. New Directions in African Fiction. Twayne, 1997. 